\title{
Ageneiosus uranophthalmus, a new species of auchenipterid catfish (Osteichthyes: Siluriformes) from river channels of the central Amazon basin, Brazil
}

\author{
Frank Raynner V. Ribeiro and Lúcia H. Rapp Py-Daniel
}

Ageneiosus uranophthalmus is described from river channels of the central Amazon basin, Brazil. The new species is widely distributed in the Amazon and is distinguished from its congeners by the V-shape snout and eye laterally placed and dorsally oriented, more visible in dorsal view than in ventral view. Ageneiosus uranophthalmus shows a range of variation on color pattern when compared with its congeners. This and other differences are described and discussed herein.

Ageneiosus uranophthalmus é descrita de canais de rios da bacia amazônica, Brasil. A nova espécie se distingue das demais congêneres pelo focinho em forma de $\mathrm{V}$ e por possuir olhos laterais e dirigidos dorsalmente, mais visíveis em vista dorsal do que em vista ventral. Ageneiosus uranophthalmus mostra uma grande variação de padrão de colorido quando comparado com outras espécies do gênero. Esta e outras diferenças são descritas e discutidas.

Key words: Taxonomy, South America, Benthic fishes, Auchenipteridae.

\section{Introduction}

Representatives of Ageneiosus La Cépède, 1803 are exclusive and widely distributed throughout lowland waters of the Neotropical region ranging from Panama, central America to Argentina, and South America (Walsh, 1990; Ferraris, 2007). Ageneiosus had two large revisions. The first was conducted by Eigenmann \& Eigenmann (1890). Those authors defined the genus on the basis of morphological characters and recognized six species as valid: $A$. atronasus Eigenmann \& Eigenmann, 1888, A. brevifilis Valenciennes in Cuvier \& Valenciennes, 1840, A. brevis Steindachner, 1881, A. pardalis Lütken, 1874, A. ucayalensis Castelnau, 1855 and $A$. valenciennesi Bleeker, 1864. The second thorough revision was conducted by Walsh (1990). In this work, the genus is represented by ten valid species: A. brevis, A. piperatus (Eigenmann, 1912), A. atronasus, A. pardalis, A. vittatus Steindachner, 1908, A. valenciennesi, A. ucayalensis, A. polystictus Steindachner, 1915, A. brevifilis and $A$. marmoratus Eigenmann, 1912, supposedly sharing two synapomorphic characters: (1) absence of mental barbels in adults, and (2) dorsal margin of the maxillary barbel of nuptial males with enlarged, tooth-like odontodes formed by outgrowths of the maxillae.
According to Ferraris (2003, 2007), Ageneiosus encompasses eleven named valid species: $A$. atronasus, $A$. brevis, A. inermis (Linnaeus, 1766), A. magoi Castillo \& Brull, 1989, A. marmoratus, A. militaris Valenciennes, 1836, A. pardalis, A. piperatus, A polystictus, A. ucayalensis, and A. vittatus. Currently, a systematic revision of the genus is under progress by the first author and an undescribed species was recognized from river channels of the central Amazon basin, described herein.

\section{Material and Methods}

Counts and measurements were made on the left side of the specimens whenever possible. All measurements are expressed as percents of standard length (SL), except subunits of the head, which are expressed as percents of head length (HL). Straight-line measurements were taken with a digital dial caliper and taken point-to-point, based on Lundberg et al. (1991), Ferraris \& Vari (1999), and Ferraris et al. (2005). Measurements included: body depth, taken at the dorsal-fin origin; body width, measured immediately posterior to pectoral-spine insertions; head length, measured parallel to the body axis, from the snout tip to the posterior edge of the bony opercle; head depth, taken at the first nuchal plate base;

Instituto Nacional de Pesquisas da Amazônia - INPA, Programa de Coleções e Acervos, Coleção de Peixes. Av. André Araújo, 2936, Petrópolis, 69011-970 Manaus, AM, Brazil. fraynner@yahoo.com.br, lucia.rapp@gmail.com 
head width, taken just posterior to the eye; eyeball diameter, taken as the largest longitudinal measure of the eyeball; snout length, from the snout tip to the anterior margin of the eye; interorbital distance, least distance between medial eye margins; predorsal length, taken from anterior edge of the first dorsal fin spine (spinelet) to the snout tip; prepelvic length, from snout tip to pelvic-fin origin; preanal length, from snout tip to anal-fin origin; pectoral-fin spine length, from origin of spine to its distal tip, not including the fleshy or flexible bony distal portion of the spine; dorsal-fin length, from origin of first branched ray to its distal tip; dorsal-fin spine length, from second spine base at junction with first spine (spinelet) to its distal tip, not including the fleshy or flexible bony distal portion; pelvic-fin length, from base to tip of first unbranched pelvic-fin ray; anal-fin base length, from anal-fin origin to posterior-most base of anal-fin insertion; projection of the snout, distance from anterior edge of mandibular symphysis to snout tip; caudal-peduncle length, from last anal-fin ray insertion to hipurals 2 and 3 joint; caudalpeduncle depth, above tip of last anal-fin ray; mouth width, transverse distance between mouth corners; end of dorsalfin base to origin of adipose-fin, from insertion of last dorsalfin ray to adipose-fin origin; second nuchal plate width, measured transversally on its base; second nuchal plate length, from its base to posterior-most tip; and distance between nares, shortest distance between rims.

Fin-ray counts include all rays. The two posterior-most dorsal- and anal-fin rays articulating to the corresponding last pterygiophore of each fin were counted as separate rays. Caudal-fin ray counts include the branched rays and the first unbranched ray of the dorsal and ventral lobes. Gill rakers were counted on the first branchial arch (ceratobranchial and epibranchial).

Osteological preparations were cleared and counterstained for cartilage and bone using the method of Taylor \& van Dyke (1985). Branchiostegal rays, procurrent caudal-fin rays and vertebral counts were taken from cleared and stained specimens (c\&s). In vertebral counts the fused PU1+ U1 is considered as a single bone, and the Weberian apparatus as having five elements. Osteological terminology follows Lundberg \& Luckenbill (2007).

The examined specimens and comparative material were kindly made available by ANSP, Academy of Natural Sciences, Philadelphia; BMNH, Natural History Museum, London; CAS, California Academy of Sciences, San Francisco; FMNH, Field Musem of Natural History, Chicago; INPA, Instituto Nacional de Pesquisas da Amazônia, Amazonas; MACN, Museo Argentino de Ciencias Naturales, Bernardino Rivadavia, Buenos Aires; MBUCV, Universidad Central de Venezuela, Museo de Biologia, Caracas; MCZ, Museum of Comparative Zoology, Cambridge; MHNM, Museo de Historia Natural, Montevideo; MNHN, Muséum National d'Histoire Naturelle, Paris; MNRJ, Museu Nacional, Rio de Janeiro; MPEG, Museu Paraense Emílio Goeldi, Belém; MZUSP, Museu de Zoologia, Universidade de São Paulo, São Paulo; NMW, Naturhistorisches Museum, Vienna; RMNH, Rijksmuseum van
Natuurlijke Historie, Leiden; USNM, National Museum of Natural History, Smithsonian Institution, Washington; ZMUC, Kobenhavns Universitet Zoologisk Museum, Copenhagen.

In the list of comparative material examined, the museum abbreviation and catalog number are followed by the total number of specimens in that lot, range of standard length, $\mathrm{PH}$ - photograph, ACSI - on-line image in All Catfish Species Inventory Image Base (http://acsi.acnatsci.org/base/, Morris et al., 2006) and collecting data.

\section{Results}

\section{Ageneiosus uranophthalmus, new species Fig. 1}

Holotype. INPA 8945, $92.1 \mathrm{~mm}$ SL, Brazil, Amazonas State, Itacoatiara, rio Amazonas below Paraná da Eva, collected with $3 \mathrm{~m}$ bottom trawl in channel $20-30 \mathrm{~m}$ deep, approximately $03^{\circ} 13^{\prime} \mathrm{S}$ 5901'W, 6 Nov 1992, C. Cox-Fernandes \& J. Lundberg.

Paratypes. Brazil, Amazonas: INPA 8257, 1, $150.1 \mathrm{~mm}$ SL, Manacapurú, rio Solimões, collected with $3 \mathrm{~m}$ bottom trawl in channel $10 \mathrm{~m}$ deep, approximately $03^{\circ} 18^{\prime} \mathrm{S} 60^{\circ} 38^{\prime} \mathrm{W}, 18$ Oct 1992 , C. Cox-Fernandes, J. Lundberg \& L. Rapp Py-Daniel. INPA 8287, 1, $71.3 \mathrm{~mm}$ SL, rio Purus, mouth of the Purus, collected with $3 \mathrm{~m}$ bottom trawl, approximately $03^{\circ} 45^{\prime} \mathrm{S} 61^{\circ} 26^{\prime} \mathrm{W}, 20$ Oct 1992, C. Cox-Fernandes, J. Lundberg \& L. Rapp Py-Daniel. INPA 8482, 3, 67.8-94.0 $\mathrm{mm}$ SL (1 c\&s, $94.0 \mathrm{~mm} \mathrm{SL})$, collected with the holotype. INPA 8508, 1, $87.4 \mathrm{~mm}$ SL, rio Amazonas, near channel of lago Tapará, above mouth of rio Madeira, collected with $3 \mathrm{~m}$ bottom trawl, approximately $03^{\circ} 19^{\prime} \mathrm{S} 58^{\circ} 55^{\prime} \mathrm{W}, 4$ Nov 1992 , C. CoxFernandes \& J. Lundberg. INPA 17966, 1, $55.6 \mathrm{~mm} \mathrm{SL}$, rio Negro, mouth of rio Cueiras, approximately $02^{\circ} 49^{\prime} \mathrm{S} 60^{\circ} 29^{\prime} \mathrm{W}, 01$ Oct 1992, L. Chao. INPA 22723, 1, 192.5 mm SL, rio Uatumã at Poço do Arraia, 29 Jan 1985, INPA Ichthyology team. INPA 22796, 1, 206.8 mm SL, Presidente Figueiredo, rio Uatumã, approximately 1 $\mathrm{km}$ downstream from Balbina dam, approximately $01^{\circ} 56^{\prime} \mathrm{S} 59^{\circ} 28^{\prime} \mathrm{W}$, 1 Mar 1983, INPA Ichthyology team. INPA 22805, 2, 213.0-230.0 mm SL, rio Uatumã, igarapé of Barreto, 27 Apr 1983, INPA Ichthyology team. INPA 31252, 1, $43.6 \mathrm{~mm} \mathrm{SL}$, rio Negro at Ponta Negra, approximately $03^{\circ} 04^{\prime} \mathrm{S} 60^{\circ} 06^{\prime} \mathrm{W}, 11$ Sep 1992, L. Chao. INPA 31253, 1, $125.5 \mathrm{~mm}$ SL, rio Solimões at Costa do Catalão, collected with $3 \mathrm{~m}$ bottom trawl in channel 7-12 m deep, 03'ㄹ'43"S 5988'39"W, 7 Aug 2008, A. Ribeiro. INPA 31254, 1, 54.0 mm SL, rio Solimões at Costa do Catalão, collected with $3 \mathrm{~m}$ bottom trawl in channel 7-9 m deep, 0312'43"S 5988'39'W, 8 Aug 2008, A. Ribeiro. MZUSP 55634, 1, $131.2 \mathrm{~mm}$ SL, rio Negro, $6.5 \mathrm{~km}$ below Jufari, collected with $3 \mathrm{~m}$ bottom trawl, approximately $01^{\circ} 17^{\prime} 37^{\prime} \mathrm{S}$ 61 ${ }^{\circ} 56$ '57''W, 9 Dec 1993, J. Friel et al. MZUSP 56894, 1, $54.9 \mathrm{~mm}$ $\mathrm{SL}$, rio Solimões near rio Purus, collected with $3 \mathrm{~m}$ bottom trawl, approximately $03^{\circ} 36^{\prime} 17^{\prime \prime} \mathrm{S} 61^{\circ} 16^{\prime} 42^{\prime \prime} \mathrm{W}, 28$ Jul 1996, M. ToledoPiza et al. MZUSP 55504, 1, rio Negro, $11.3 \mathrm{~km}$ below Curidique, 01'58'26"S 6116'12”W, 5 Dec 1993, J. Lundberg et al. MZUSP 55511,1 , rio Negro, $18 \mathrm{~km}$ above rio Branco, 01 ${ }^{\circ} 14^{\prime} \mathrm{S} 61^{\circ} 59^{\prime} \mathrm{W}, 9$ Dec 1993, J. Lundberg et al. MZUSP 55513, 1, rio Negro, 14.8 km below Jufari, 1²1'36”S 6154'48”W, 9 Dec 1993, J. Lundberg et al. MZUSP 55514, 1, rio Negro, 12 km below Tarumã-Mirim, $03^{\circ} 08^{\prime} \mathrm{S}$ $60^{\circ} 04^{\prime}$ W, 20 Oct 1993, J. Lundberg et al. MZUSP 55639, 1, rio 
Negro, 27.4 km below Caures, 1²3'13"S 6154'3”W, 8 Dec 1993, J. Friel et al. MZUSP 56082, 2, rio Negro, $18.5 \mathrm{~km}$ below Paraná do Cantagalo, 01\%41'52"S 6126'49”W, 6 Dec 1993, J. Friel et al. MZUSP 56083, 1, rio Negro, 7.4 km below Jufari, 01¹8'12”S 6157'41'W, 9 Dec 1993, J. Friel et al. MZUSP 56237, 1, rio Negro, 11.5 km below Curidique, 158'25"S 61¹6'10”W, 5 Dec 1993, J. Lundberg et al. MZUSP 58019, 1, rio Amazonas, $18 \mathrm{~km}$ below rio Madeira, 0319'19'S 58³5'08'W, 10 Aug 1996, C. Cox-Fernandes et al. MZUSP 58021, 1, rio Amazonas, 10 miles below rio Negro, 0305'42”S 5947'48”W, 22 Jul 1996, C. Cox-Fernandes et al. MZUSP 58133, 1, rio Negro, $6.1 \mathrm{~km}$ below Tarumã-Mirim, 0304'13"S 60¹1'49'W, 9 Oct 1994, M. Westneat et al. MZUSP 63574, 1, Cassiã, rio Purus, 3 Jan 1975, P. Vanzolini.

Diagnosis. Ageneiosus uranophthalmus is distinguished from its congeners by the $\mathrm{V}$-shape snout ( $v s$. rounded snout); each upper and lower jaw narrowing anteriorly (Fig. 2); eye laterally placed and dorsally oriented, more visible in dorsal view than in ventral view (vs. more visible in ventral view than in dorsal view in all other Ageneiosus species). It can be further distinguished from $A$. atronasus, $A$. magoi, $A$. piperatus, $A$. polystictus, $A$. valenciennesi and $A$. vittatus, by the larger number of anal-fin rays (41-49, mode 47 vs. 23-39). Differ further from $A$. inermis and $A$. marmoratus by the possession of forked caudal fin ( $v s$. truncate or emarginate). Differ further from $A$. brevis by the uniform coloration, with a brownish to black dorsolateral band ( $v s$. presence of dark dots along flanks); and larger number of anal-fin rays (41-49, mode $47 v s$. 29-42). Differ from $A$. pardalis by the uniform coloration, with a brownish to black dorsolateral band ( $v s$. presence of midlateral and sublateral broken dark stripes); longer anal-fin base length (34.6-39.4 vs. 23.0-32.0\% SL, according to Walsh, 1990); and larger number of anal-fin rays (41-49, mode 47 s.

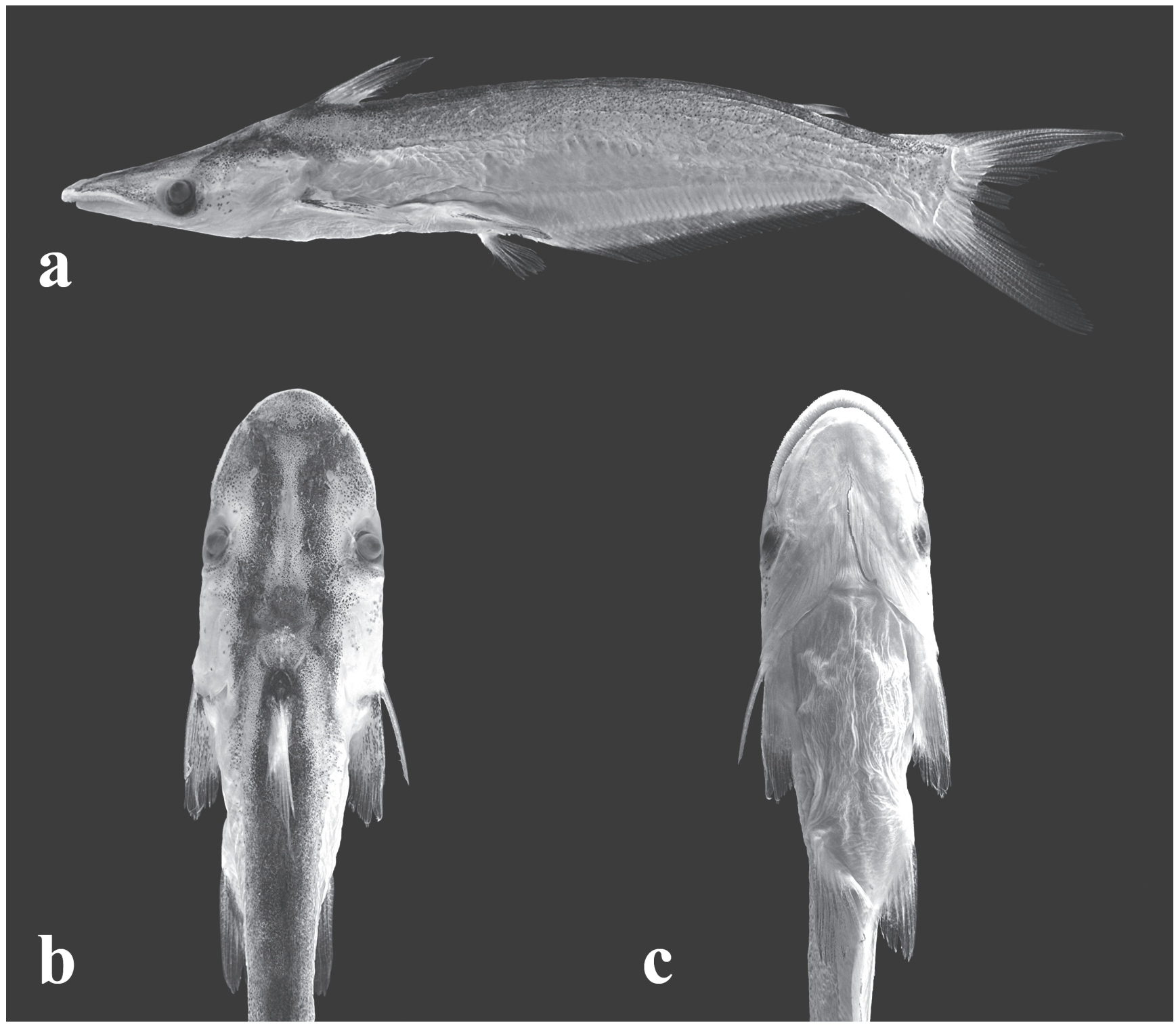

Fig. 1. Ageneiosus uranophthalmus, holotype, INPA 8945, $92.1 \mathrm{~mm}$ SL, Brazil, Amazonas State, Itacoatiara, rio Amazonas below Paraná da Eva, in lateral (a), dorsal (b), and ventral (c) views. 
35-42, according to Walsh, 1990). Ageneiosus uranophthalmus is further distinguished from $A$. ucayalensis by the fewer number of gill rakers on first branchial arch (1116 , mode $13 v s .17-25$, mode 22) and dorsal and pectoral spines becoming progressively flexible distally in individuals greater than $100 \mathrm{~mm}$ SL (vs. dorsal and pectoral spines strong and distally pointed).

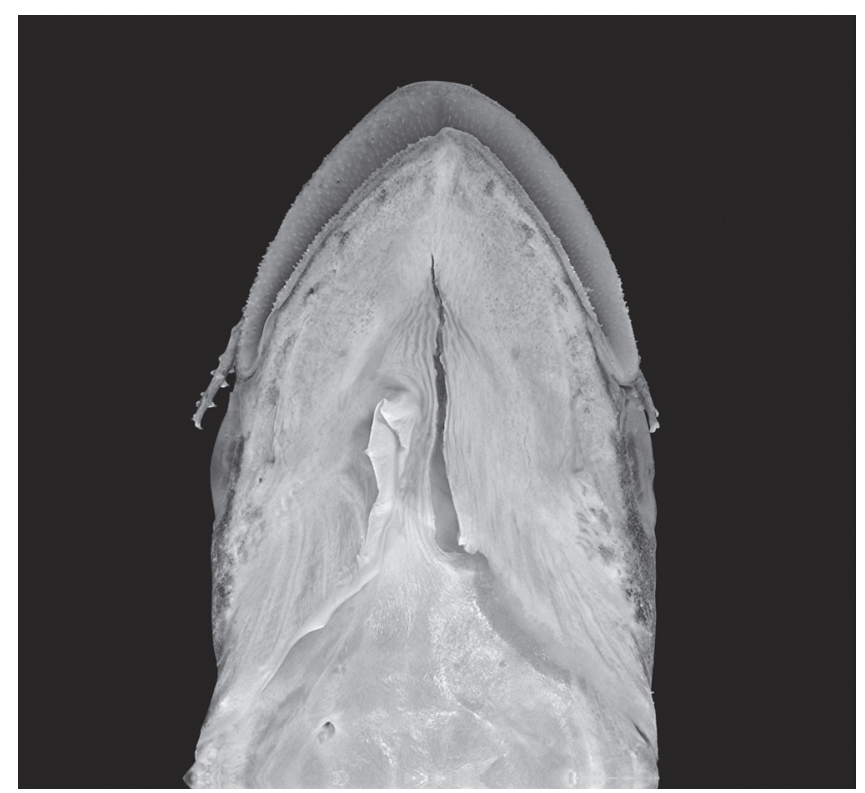

Fig. 2. Ageneiosus uranophthalmus, paratype, INPA 22723, $192.5 \mathrm{~mm}$ SL. Ventral view of the head.

Description. Morphometric data for holotype and 14 paratypes presented in Table 1. A medium-sized Ageneiosus, largest specimen examined $230.0 \mathrm{~mm}$ SL. Body relatively elongated, depth at dorsal-fin origin (13.3-17.4\% SL) proportionally higher than body width (11.5-14.7\% SL). Dorsal profile of body straight to concave from snout tip to dorsal-fin origin; straight to slightly concave from dorsal insertion to adipose-fin origin, gently sloping to beginning of caudal peduncle. Dorsal and ventral profiles of caudal peduncle slightly concave. Ventral profile of head straight to anterior region of isthmus; ventral profile of body slightly convex or straight to anal-fin origin; rising in a straight line along anal fin. Head depressed anteriorly, trunk and caudal peduncle progressively more compressed towards caudal fin. Lateral line complete and midlateral; canal forming irregular zig-zag pattern, with oblique, short, posteriorly directed branches in whole extension. Total vertebrae 51, being 17 precaudal (seven ribbed), and 34 caudal; first pleural rib on sixth vertebra.

Head covered by thin skin. Snout much projected anteriorly, pointed; snout length 51.6-56.9\% HL. Eye small $(10.2-17.3 \% \mathrm{HL})$, laterally placed, dorsally oriented, more visible in dorsal view than in ventral view. Single pair of maxillary barbels, small and filamentous (excepting nuptial males, see Sexual dimorphism, below); maxillary barbels in deep groove at mouth corners. Mouth wide, subterminal, and much projected anteriorly; upper jaw extending beyond lower jaw by shorter distance than horizontal eye diameter. Posteriormost mouth corners extending beyond vertical through posterior nostril by distance approximately equal to horizontal eye diameter. Upper and lower lips thin; poorly developed.

Jaw teeth minute, slender and conical; teeth arranged in irregular rows, laterally exposed in both upper and lower jaws. Tooth patches anteriorly wide, narrowing posteriorly. Tooth patches of upper jaw almost completely exposed when mouth closed; completely exposed on posterior corner. Number of tooth rows increase with size; specimens greater than $100 \mathrm{~mm}$ of SL with 15-20 anterior and 5-8 posterior rows on upper jaw and 11-16 anterior and 9-13 posterior rows on lower jaw; specimens smaller than $100 \mathrm{~mm}$ SL with 8-15 anterior and 3-6 posterior rows on upper jaw and 9-11 anterior and 7-11 posterior rows on lower jaw.

Cranial fontanel triangularlly elongated in dorsal view, open from mesethmoid to supraoccipital base, terminating behind vertical through posterior margin of eye. Branchiostegal membrane broadly attached to isthmus, supported by 9 branchiostegal rays. Gill opening relatively wide, its posterior margin extending to horizontal through pectoral-spine base. Gill rakers well-ossified, sharp and slender; 11-16 (mode $=13$ ) on first branchial arch; 2-4 on epibranchial $($ mode $=3), 9-13$ on ceratobranchial $($ mode $=10 ; n=15)$. Anterior internarial width greater than posterior one; posterior nostril closer to anterior nostril than to orbit. Each nostril surrounded by very low fleshy rim, more visible in larger specimens.

Dorsal-fin origin located posterior to vertical through

Table 1. Morphometric data of Ageneiosus uranophthalmus. Range includes the holotype $(\mathrm{H})$.

\begin{tabular}{|c|c|c|c|c|c|}
\hline Measurements & $\mathrm{H}$ & $\mathrm{n}$ & Low & High & Mean \\
\hline Standard length (mm) & 92.1 & 15 & 43.7 & 230.0 & 118.0 \\
\hline \multicolumn{6}{|c|}{ Percents of standard length } \\
\hline Predorsal length & 29.3 & 15 & 27.0 & 33.4 & 29.7 \\
\hline Preanal length & 53.6 & 15 & 53.3 & 58.2 & 56.2 \\
\hline Prepelvic length & 44.8 & 15 & 44.0 & 48.0 & 46.3 \\
\hline Head length & 28.6 & 15 & 27.2 & 32.3 & 29.0 \\
\hline Caudal peduncle length & 8.3 & 15 & 8.0 & 10.3 & 9.0 \\
\hline Caudal peduncle depth & 8.0 & 15 & 7.5 & 9.0 & 8.0 \\
\hline $\begin{array}{l}\text { End of dorsal-fin base to origin } \\
\text { of adipose-fin distance }\end{array}$ & 50.9 & 15 & 44.4 & 50.9 & 48.6 \\
\hline Anal-fin base & 39.4 & 15 & 34.6 & 39.4 & 37.4 \\
\hline Pelvic-fin length & 11.7 & 15 & 10.8 & 12.2 & 11.3 \\
\hline Dorsal-fin length & 13.0 & 14 & 13.1 & 18.3 & 14.1 \\
\hline Dorsal-spine length & 12.1 & 9 & 8.4 & 30.2 & 13.9 \\
\hline Pectoral-spine length & 10.3 & 14 & 9.4 & 11.7 & 10.5 \\
\hline Body depth & 14.5 & 15 & 13.3 & 17.4 & 15.1 \\
\hline Body width & 12.3 & 15 & 11.5 & 14.7 & 12.9 \\
\hline \multicolumn{6}{|c|}{ Percents of head length } \\
\hline Head depth & 44.9 & 15 & 40.7 & 47.4 & 43.6 \\
\hline Head width & 60.0 & 15 & 53.9 & 62.2 & 59.2 \\
\hline Interorbital width & 41.5 & 15 & 38.5 & 48.0 & 42.9 \\
\hline Snout length & 51.8 & 15 & 51.6 & 56.9 & 54.1 \\
\hline Snout projection & 7.3 & 15 & 6.5 & 9.8 & 8.0 \\
\hline Internarial length & 15.5 & 15 & 12.5 & 17.6 & 15.2 \\
\hline Anterior internarial width & 32.3 & 15 & 28.3 & 35.1 & 31.5 \\
\hline Posterior internarial width & 24.6 & 15 & 22.7 & 27.4 & 24.6 \\
\hline Eyeball diameter & 11.2 & 15 & 10.2 & 17.3 & 12.2 \\
\hline Mouth width & 51.6 & 15 & 47.2 & 55.6 & 50.6 \\
\hline Second nuchal plate width & 14.9 & 15 & 13.2 & 20.1 & 15.8 \\
\hline Second nuchal plate length & 14.8 & 15 & 12.1 & 17.6 & 15.0 \\
\hline
\end{tabular}


pectoral-fin origin. Dorsal-fin spine slender, straight; strong and pungent in juveniles (smaller than $100 \mathrm{~mm} \mathrm{SL}$ ), becoming progressively flexible distally in adults (greater than $100 \mathrm{~mm}$ $\mathrm{SL}$ ); anterior medial margin with numerous small osseous granulations along proximal half in specimens smaller than $100 \mathrm{~mm}$ SL, and along almost entire spine in larger specimens (excepting nuptial males, see Sexual dimorphism, below); posterior margin with medial row of widely spaced and reduced dentitions. Dorsal fin I,5 $(n=15)$; last branched ray very small. Adipose fin relatively small and largely variable in shape, from triangular to quadrangular shaped; its origin anterior to end of anal-fin base. Caudal fin deeply forked, with pointed lobes. Outermost branched rays twice as long as middle rays. Upper caudal-fin lobe slightly longer than lower lobe, its outer principal rays non-filamentous, $8+9$ principal rays, 17 upper procurrent, 15 lower procurrent rays $(\mathrm{n}=15)$. Anal-fin base longer than predorsal length, 34.6$39.4 \%$ in SL. Anal-fin origin located at or slightly posterior to vertical through tip of the innermost pelvic-fin rays. Last unbranched and three anteriormost branched anal-fin rays more developed; rays decreasing slightly in length posteriorly. Anal-fin margin straight to slightly convex. Anal-fin rays ivv, 37-45 (mode $=43, \mathrm{n}=14)$; anal-fin distal pterygiophores 43 . Pelvic-fin margin rounded; i,6; first branched ray longest. Pelvic-fin origin located at or slightly anterior to vertical through depressed first branched dorsal-fin ray. Pectoral fin with I,12-13 (mode $=13 ; \mathrm{n}=15)$; first branched ray more developed, subsequent rays decreasing in size. Pectoral-fin spine changes with age. Spine of juveniles (less than $100 \mathrm{~mm}$ SL) strong, distally pointed, continued in filamentous ray; dorsal and ventral surfaces smooth; posterior margin with, uniformly retrorse, unicuspid, 8-13 dentations $(n=9)$; anterior margin with osseous granulations along proximal half. Spine of adults (more than $100 \mathrm{~mm} \mathrm{SL}$ ) rigid proximally, becoming progressively flexible distally; dorsal and ventral surfaces smooth; anterior and posterior margins with osseous granulations along proximal half.

Color in alcohol. Body ground coloration white to yellowish. Brownish to black dorsolateral band extending from head to upper caudal-fin base and with variable thickness - restricted to dorsal area (in individuals smaller than $120.0 \mathrm{~mm} \mathrm{SL}$ ) to extending ventrally onto lateral line (in individuals greater than $190.0 \mathrm{~mm} \mathrm{SL}$ ). Dorsolateral band commonly broken into longitudinal series of prominent blotches or appearing somewhat mottled. Lateral and ventral surfaces of body light, with scattered dark pigmentation of variable intensity, usually concentrated on dorsal portion of body (two individuals from rio Negro, INPA 17966 and 31252, with lateral surface of body much pigmented; brownish). Dorsal surface of head completely covered with irregular mottled pattern consisting of dark brown blotches or brownish (in individuals larger than $150 \mathrm{~mm} \mathrm{SL}$ ). Smaller specimens (below $130 \mathrm{~mm} \mathrm{SL}$ ) with two dark bands running parallel from middle of snout, along each margin of fontanel, to level of dorsal-fin insertion. These bands crossed by dark area on mesethmoid and on nuchal plate. Abdomen unpigmented.

Fins with marked ontogenetic variation. Smaller specimens usually with dark bands on pectoral, pelvic completely dark, anal fin with distal dark band; dorsal and caudal fins hyaline. Above $130 \mathrm{~mm} \mathrm{SL}$, general fin coloration faint, with faded dark bands on anal fin, pelvic brownish, but dark bands still present on pectoral in most specimens. In these larger specimens, dorsal fin with anteriormost rays darker; caudal fin pigmentation vary from presence of dark basal band, followed by hyaline band and dark-pointed tips of the lobes to complete hyaline.

Barbels with scattered dark chromatophores, appearing white or dark.

Sexual dimorphism. The single mature males has strong morphological modifications already known to occur in representatives of the genus. The nuchal region in nuptial males (from frontal to nuchal plates; Fig. 3) shows a much more acute angle than in females and nonbreeding males. The ossification of the maxillary barbel begins at its base and proceeds towards its tip, resulting in a small, thickened, rigid barbel, reaching beyond anterior eye margin. The dorsal and medial surfaces of the barbel are covered with sharp, unicuspid dentations; the dorsal row with eight dentations along full ext=ension of the barbel and the medial row with four dentations along distal half.

The dorsal fin is modified. The first branched dorsal-fin ray is longer than in nonbreeding males and females. The dorsal-fin spine is straight, more rigid and elongate, its length is about two times the length of the first branched ray; the anterior margin with two rows of numerous, uniformly retrorse, unicuspid dentations, becoming progressively less prominent and pungent and more concentrated proximally; rows of dentations ending proximally on a large osseous tubercle. The dorsal-fin spine of males can be hyperextended anteriorly to approximately a $45^{\circ}$ dorso-anterior angle, instead of the near-vertical limit of females and juveniles.

The anterior portion of male anal-fin is highly modified in comparison to that in non-breeding specimens. The unbranched and the three anteriormost branched anal-fin rays are elongate and joined together, modified as a structural support for the intromittent organ. The genital pore is at the intromittent organ tip. In adult females, the unbranched and two or three anterior branched anal-fin rays are much longer than the subsequent rays.

Ecology. Juveniles of Ageneiosus uranophthalmus were taken in small bottom trawls in swiftly flowing open channels over sand, clay and detritus substrates. Approximate depth of capture between $5-30 \mathrm{~m}$. The largest specimens were collected with gillnets only in the rio Uatumã.

Distribution. Ageneiosus uranophthalmus is known from the middle reaches of the Amazon Basin, Brazil (Fig. 4), mainly rio Amazonas, rio Solimões, rio Negro, rio Purus and middle rio Uatumã. 


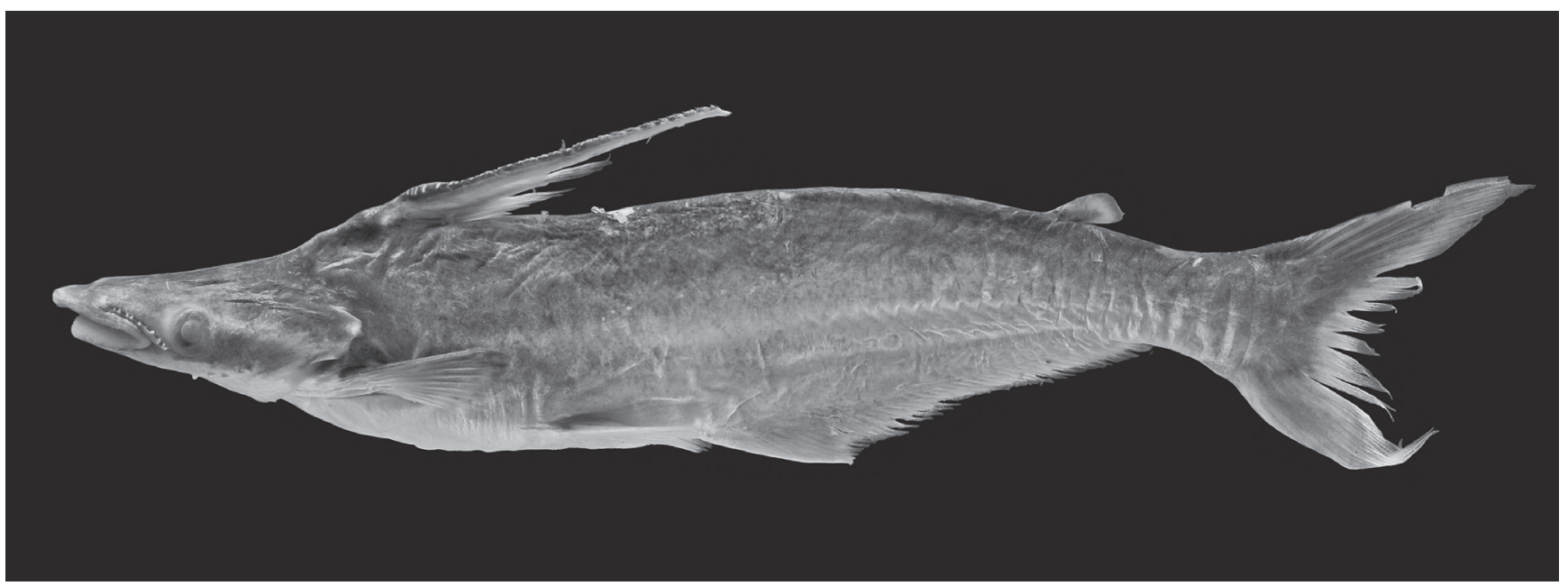

Fig. 3. Ageneiosus uranophthalmus, paratype, INPA 22723, $192.5 \mathrm{~mm}$ SL, nuptial male in lateral view.

Etymology. The specific epithet, uranophthalmus, is derived from the Greek ouranos (sky, heaven) and ophthalmos (eye) in allusion to the dorsally oriented eyes.

Remarks. The new species herein described exhibit the osteological and sexually dimorphic features proposed as synapomorphic for the family Auchenipteridae (Ferraris, 1988; Royero, 1999). Within the Auchenipteridae, Ageneiosus uranophthalmus shares with its congeners the two characters states proposed by Walsh (1990) as synapomorphic for the genus: absence of mental barbels in adults, and dorsal margin of the maxillary barbel of nuptial males with enlarged, toothlike odontodes formed by outgrowths of maxillae.

More than 30 specific names were proposed in Ageneiosus. More than 20, however, have been considered synonyms of the 11 named valid species actually recognized (Walsh, 1990; Ferraris, 2003, 2007). A comparative analysis with types and original descriptions allowed concluding that the diagnostic

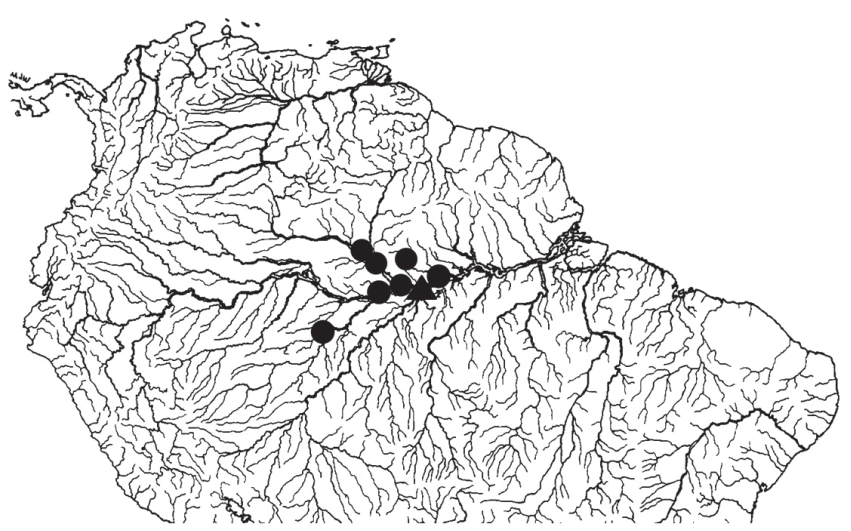

Fig. 4. Drainage map of northern South America illustrating the geographic distribution of Ageneiosus uranophthalmus. Type locality represented by triangle. Some symbols represent more than one locality or lot of specimens. Base map by Marilyn Weitzman. characters of $A$. uranophthalmus are unique within the auchenipterids. The intrageneric biodiversity and relationships of Ageneiosus are still under investigation.

Comparative material. Ageneiosus atronasus: Brazil, Amazonas: INPA 18557, 63.1-115 mm SL, rio Purus, lago Samauma. INPA 13392, 1, $104.0 \mathrm{~mm}$ SL, rio Solimões, ilha da Marchantaria. INPA 18988, 8, 81.6-93.0 mm SL, rio Solimões, lago Mamirauá. Rondônia: INPA 10945, 1, $106.8 \mathrm{~mm}$ SL, rio Jaci-Paraná. INPA 10955, 2, 94.0-102 .0 mm SL, rio Jaci-Paraná. Bolivia: INPA 651, 6, 96.1-116.0 mm SL, laguna Capital, rio Mamorí. Ageneiosus brevis: Brazil, Amazonas: NMW 47801 (2), Syntypes, rio Amazonas near Coari and Hyavary. INPA 11759, 5, 117.2-165.4 mm SL, rio Amazonas, ilha do Careiro. INPA 13393, 1, $111.1 \mathrm{~mm}$ SL, rio Solimões, ilha da Marchantaria. INPA 22139, 7, 113.8-162.0 mm SL, rio Solimões, lago do Rei. INPA 26537, 1, 115.6 mm SL, Manaus, mouth of the rio Negro. Pará: INPA 22722, 2, 115.0-116.0 mm SL, rio Amazonas, Lago Grande de Monte Alegre. Rondônia: INPA 21720, 1, $117.7 \mathrm{~mm}$ SL, rio Guaporé, rio Cautário. Bolívia: INPA 652, 2, 106.8-117.6 mm SL, Bolívia. Ageneiosus inermis: Brazil, Amazonas: INPA 27415, 2, 167.0-237.3 mm SL, Coari, lago Catuá, 345'36”'S 6407'14”'W. INPA 27416, 1, $199.1 \mathrm{~mm}$ SL, Coari, lago Ipixuna, 351'42”S 6352'52”W. MZUSP 36110 , 1 , not measured, rio Japurá, igarapé Ubi, lago Amanã. MZUSP 56080, 4, not measured, rio Purus, 3०44'32"S 6126'41'W. Mato Grosso: MZUSP 52326, 2, not measured, Bandeirantes, rio Araguaia. MZUSP 94079, 1, not measured, Canarana, rio Xingu, rio Culuene, lago da Mirian, $13^{\circ} 25^{\prime} 48^{\prime \prime} \mathrm{S}$ $53^{\circ} 02^{\prime} 24^{\prime}$ 'W. Mato Grosso do Sul: MZUSP 27194, 2, not measured, rio Paraguai, ilha de Taiamã. Pará: INPA 680, 1, 217.5 mm SL, rio Curuá-Una. MPEG 2656, 1, not measured, rio Goiapi, Taperebá, cachoeira do Arari, Ilha de Marajó. Rondônia: INPA 21708, 1, 198.9 mm SL, Vale do Guaporé, rio Novo, 11'29'28"S 6434'34.5”W. MZUSP 37424, 1, not measured, rio Guaporé, rio Branco. Peru: MZUSP 26411, 1, not measured, rio Ucayali. Ageneiosus magoi: Venezuela, Estado Guárico: MBUCV V-15666, Holotype PH, Los esteros 
de Camaguán, km 270. Ageneiosus marmoratus: British Guiana: FMNH 53245, Holotype PH, 148.0 mm SL, Creek below Potaro Landing. Brazil, Pará: MPEG 7902, 3, 141.0$212.0 \mathrm{~mm}$ SL, rio Xingu, rio Curuá, rio Parazinho. Ageneiosus militaris: Brazil, Rio Grande do Sul, Itaqui: MZUSP 1987, 3, 168.0-206.0 mm SL, rio Uruguay, 56 $36^{\prime} 00^{\prime}{ }^{\prime} \mathrm{W} 29^{\circ} 08^{\prime} 00^{\prime \prime}$ 'S. MZUSP 63628, 2, 220.0-260.0 mm SL, rio Uruguay, 56 $56^{\circ} 00^{\prime \prime} \mathrm{W}$ $29^{\circ} 08^{\prime} 00$ 'S. Mato Grosso do Sul, Tacurú: MZUSP 64241, 1,

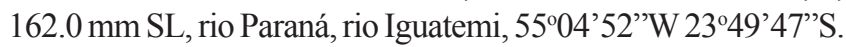
Ageneiosus pardalis: Venezuela: ZMUC P 29664, Holotype PH, Caracas. USNM 121260, Holotype of Ageneiosus freiei $\mathrm{PH}$, rio Agua Caliente, 2 to $3 \mathrm{~km}$ above lago Maracaibo. Colômbia: NMW 47811 (1 of 2) Syntypes of Ageneiosus caucanus, rio Cauca. Ageneiosus piperatus: British Guiana: FMNH 53243, Holotype, ACSI as Tympanopleura piperata, Crab Falls, Essequibo River. Brazil, Amazonas: INPA 12584, 5, not measured, rio Negro, rio Jaú, mouth of rio Taunini. INPA 12603, 13, not measured, rio Negro, rio Jaú, mouth of rio Taunini. INPA 12608, 8, not measured, rio Negro, rio Jaú, above rio Taunini. INPA 12613, 4, 29.3-50.7 mm SL, rio Negro, rio Jaú, above Taunini. INPA 10263, 1, $41.4 \mathrm{~mm} \mathrm{SL}$, rio Solimões, Marchantaria. INPA 10263, 1, not measured, rio Negro, lago do Trato. INPA 12562, 4, not measured, rio Negro, rio Jaú, lago Copaíba. INPA 12564, 13, not measured, rio Negro, rio Jaú, lago Copaíba. INPA 12636, 176 (3), 49.5-54.3 mm SL, rio Negro, rio Jaú, lago Tambor Velho. INPA 12682, 39 (5), 41.4-46.7 mm SL, rio Negro, rio Jaú. Ageneiosus polystictus: Brazil, Amazonas: INPA 11357, 1, $83.6 \mathrm{~mm}$ SL, rio Negro, rio Jaú. INPA, 12629, 1, 190.0 mm SL, rio Negro, rio Jaú, rio Taunini. INPA 12640, 7, 88.4-142.1 mm SL, rio Negro, rio Jaú, rio Preto. INPA 17996, 1, $128.4 \mathrm{~mm} \mathrm{SL}$, rio Negro, rio Cuieiras. INPA 22809, 1, 221.8 mm SL, Presidente Figueiredo, rio Uatumã. MZUSP 56079, 1, not measured, rio Juapiris, $1^{\circ} 34^{\prime} 46^{\prime \prime} \mathrm{S}$ $61^{\circ} 28^{\prime} 38^{\prime \prime}$ W. MZUSP 56091, 1, not measured, rio Negro, 1'50'58'S 61'24'4”'W. MZUSP 59064, 1, not measured, rio Negro, rio Arirará. MZUSP 59068, 3, not measured, rio Negro, rio Daraá, cachoeira do Aracú. MZUSP 73478, 1, not measured, rio Negro, Anavilhanas, $2^{\circ} 42^{\prime} \mathrm{S} 60^{\circ} 45^{\prime} \mathrm{W}$. MZUSP 93434, 2, not measured, rio Negro, rio Tiquié, $00^{\circ} 10^{\prime} 00^{\prime \prime} \mathrm{S}$ 6907'00'W. Ageneiosus ucayalensis: Brazil, Amazonas: INPA 8181, 7, 106.1-147.9 mm SL, rio Purus, near mouth of Purus. INPA 8426, 1, $78.1 \mathrm{~mm}$ SL, rio Negro, between rios Tarumã and Tarumã-Mirim. INPA 18068, 3, 26.6-108.8 mm SL, rio Negro at Ponta Negra. INPA 18087, 3, 117.8-125.8 mm SL, rio Negro, mouth of rio Cueiras. INPA 18922, 1, $230.0 \mathrm{~mm} \mathrm{SL}$, rio Japurá, mouth of lago Mamirauá. MZUSP 55517, 3, 57.0$79.6 \mathrm{~mm}$ SL, Altazes, rio Madeira, between Paraná do Urucurituba and Paraná do Capitari. MZUSP 56838, 3, 35.2$65.3 \mathrm{~mm}$ SL, rio Japurá, between Paraná do Juruá and rio Solimões. Pará: INPA 5073, 3, not measured, rio Trombetas, rio Cuminá, lago Salgado. INPA 22629, 1, not measured, rio Tocantins, Poço do Paulo. INPA 22740, 2, 149.2-171.0 mm SL, rio Tocantins, Poço do Paulo. INPA 22818, 2, 179.7-188.6 $\mathrm{mm}$ SL, rio Trombetas, Cachoeira Porteira. MZUSP 5720, 7 , 88.5-157.6 mm SL, Santarém, rio Tapajós. MZUSP 74700, 1 , $128.8 \mathrm{~mm}$ SL, rio Amazonas, Ituquara canal, below Gurupá.
MZUSP 74872, 4, 123.0-165.0 mm SL, Barcarena, Taperebá. Tocantins: INPA 20146, 1, $166.2 \mathrm{~mm}$ SL, Caseara, rio Araguaia, lago Volta Grande. Ageneiosus vittatus: Brazil, Acre: MZUSP 53079, 1, $186.0 \mathrm{~mm}$ SL, rio Juruá, Reserva Extrativista do alto rio Juruá. Amazonas: MZUSP 92185, 2, 154.8-184.7 mm SL, rio Negro, rio Tiquié, 6941'26”'W 0004'41'”N. MZUSP 93034, $1,139.2 \mathrm{~mm}$ SL, rio Negro, rio Tiquié, $69^{\circ} 41^{\prime} 00^{\prime \prime} \mathrm{W} 00^{\circ} 04^{\prime} 00^{\prime \prime} \mathrm{N}$. MZUSP 93076, 1, $139.2 \mathrm{~mm}$ SL, rio Negro, rio Tiquié, 69³5'00”'W 00¹1'00’'N.

\section{Acknowledgements}

We thank Osvaldo Oyakawa (MZUSP), José Lima de Figueiredo (MZUSP) and Wolmar Wosiacki (MPEG) for the assistance dedicated to FRVR during his visit to the collections under their care and for the loan of the specimens; Helmut Wellendorf (NMW) for the loan of syntypes and providing photographs; Paulo Buckup (MNRJ) for the loan of types; James Maclaine and Patrick Campbell (BMNH); Karsten Hartel (MCZ); John Lundberg and Mark Sabaj Perez (ANSP); Romain Causse, Zora Gabsi and Claude Ferrara (MNHN); Ronald Ruiter (RMNH); Sandra J. Raredon (USNM); and Tammes Menne (ZMUC) for providing radiographic images and photographs of the types. We are grateful to André Canto (INPA) for the images and Ariana Ribeiro (INPA) for the donation of specimens. This paper was greatly improved by the comments and suggestions of the editorial board and anonymous two referees.

\section{Literature Cited}

Eigenmann, C. H. \& R. S. Eigenmann. 1890. A revision of the South America Nematognathi or catfishes. Occasional Papers of the California Academy of Sciences, 1(2): 1-508.

Ferraris, C. J., Jr. 1988. The Auchenipteridae: Putative monophyly and systematics, with a classification of the Neotropical doradoid catfishes (Ostariophysi: Siluriformes). Unpublished Ph.D. Dissertation, University of New York, New York, 229p.

Ferraris, C. J., Jr. 2003. Family Auchenipteridae. Pp. 470-482. In: Reis, R. E., S. O. Kullander \& C. J. Ferraris, Jr. (Eds). Check List of the Freshwater Fishes of South and Central America. Porto Alegre, Edipucrs, 729p.

Ferraris, C. J., Jr. 2007. Checklist of catfishes, recent and fossil (Osteichthyes: Siluriformes), and catalogue of siluriform primary types. Zootaxa, 1418: 1-628.

Ferraris, C. J., Jr. \& R. P. Vari. 1999. The South American catfish genus Auchenipterus Valenciennes, 1840 (Ostariophysi: Siluriformes: Auchenipteridae): monophyly and relationships, with a revisionary study. Zoological Journal of the Linnean Society, 126: 387-450.

Ferraris, C. J., Jr., R. P. Vari \& S. J. Raredon. 2005. Catfishes of the genus Auchenipterichthys (Osteichthyes: Siluriformes: Auchenipteridae); a revisionary study. Neotropical Ichthyology, 3(1): 89-106.

Lundberg, J. G., A. H. Bornbusch \& F. Mago-Leccia. 1991. Gladioglanis conquistador $\mathrm{n}$. sp. from Ecuador with diagnoses of the subfamilies Rhamdiinae Bleeker and Pseudopimelodinae n. subf. (Siluriformes: Pimelodidae). Copeia, 1991(1): 190-209. 
Lundberg, J. G. \& K. Luckenbill. 2007. Pimelodus maculatus: dry skeleton images. Available from: http://catfishbone.acnatsci.org/ Pimelodidae/Pimelodus/maculatus/dry.skeleton.html (October 30, 2008).

Royero, R. L. 1999. Studies on the systematics and phylogeny of the catfish family Auchenipteridae (Teleostei: Siluriformes). Unpublished Ph.D. Dissertation, University of Bristol, Bristol, $377 \mathrm{p}$.

Taylor, W. R. \& G. C. van Dyke. 1985. Revised procedures for staining and clearing small fishes and other vertebrates for bone and cartilage study. Cybium, 9: 107-119.

Walsh, S. J. 1990. A Systematic Revision of the Neotropical Catfish Family Ageneiosidae (Teleostei: Ostariophysi: Siluriformes). Unpublished Ph.D. Dissertation, University of Florida, Gainesville, 363p.

Accepted November 23, 2009

Published March 31, 2010 